\title{
Factors Inhibiting The Mentally Challenged In The Acquisition Of Skills In Ugenya District, Siaya County, Kenya
}

\author{
Doreen Awino Opondo \\ Department of Education Management, Kisii University \\ Prof. I.N. Kimengi \\ Department of Educational Foundations, Moi University \\ Dr. James Sika \\ Department of Educational Management, Maseno University
}

\begin{abstract}
The purpose of the study was to establish the factors inhibiting the mentally challenged in the acquisition of skills. The study was guided by the following research objectives: To establish the challenges facing mentally handicapped learners in acquisition of learning skills in special schools and units; to establish the effect of parents and community support and involvement on the acquisition of learning skills among mentally handicapped learners in special schools and units; to determine the effect of the role of teachers and teaching methods used on the acquisition of learning skills among mentally handicapped learners in special schools and units and to find out the effect of learners characteristics on the acquisition of learning skills among mentally handicapped learners in special schools and units. Descriptive survey design was used because of its possibility to acquire information about people and their characteristics, attitudes and previous experiences. The study targeted parents/guardians and teachers in the schools studied. Purposive sampling techniques were used to sample the respondents. A total of 76 respondents responded to the research instruments. Questionnaires and interview schedules were used as instruments for data collection. Both quantitative and qualitative data analysis techniques were used to analyze the data. Statistical Package for Social Sciences (SPSS) package was used to analyze the quantitative data while content analysis was used to analyze the qualitative data from the interview schedules. Descriptive statistics such as frequencies, percentages, means and standard deviation was used to analyze the data. Among the major findings, the study established that the major challenges facing the acquisition of leaning among the mentally handicapped included: students' involvement in interruptive behaviours which interferes with cognitive functioning and inability to cope with frustrations. The role of teachers and teaching methods was not a hindrance to the acquisition of learning skills among the mentally challenged students. The study recommended that awareness should be created through dissemination of information on mental handicap learners. The study suggests a comparative study on the process of acquisition of learning skills be done among normal and mentally challenged learners.
\end{abstract}

Key Words: mentally challenged, skills, disabled, mentally handicapped, parents, teachers', community, schools, learning

\section{INTRODUCTION}

Education is a key in the protection of democratic institutions and human rights through wellinformed citizens. The education of the mentally challenged is equally important. These are children with substantial limitations in present functioning as characterized by significant subaverage intellectual functioning existing with related limitations in two or more of the 
Opondo, D. A., Kimengi, I. N., \& Sika, J. (2015). Factors Inhibiting the Mentally Challenged in the Acquistion of Skills in Ugenya District, Siaya county, Kenya. Advances in Social Sciences Research Journal, 2(4) 149-160.

following applicable adaptive skill areas such as communication, self care, home living, social skills, community use, self direction, health and safety, functional academics, leisure and work. All these manifests during the developmental period (0-18) years (Mwaura, 2002).

One major challenge in Kenya is that the mentally challenged persons are looked down upon by the members of the community yet they need to learn and be guided so as to fit in the society. The mentally handicapped are limited in their intellectual capabilities (K.I.E, 2001). During school years, they show extreme difficulties in academic subjects and may not progress beyond class one. Others show marked deficits in adaptive behavior in most cases severe impairment as evident from birth. Many children with disability suffered neglect and rejection (Ngugi, 2002). They are also referred to as children with developmental disabilities. These children also deviate to a relatively minor or major degree in their level of functioning from the 'normal' children of the same chronological age depending on their category. These children experience academic and daily living problems in inclusive setting and this is why some moderate, severe and profound cases are put in special schools and units (Mwaura, 2002).

The government of Kenya is also committed to the protection and provision of equal opportunities to persons with special needs. The government has developed a number of policy guidelines for SNE dating back to 1964. These include: Committee on Care and Rehabilitation of the Disabled led by Ngala Mwendwa (1964), National Education Commission on Education Objectives and Policies (Gachathi Report, 1976) and the Task Force on Special Needs Education (Kochung Report, 2003).

The Persons with Disabilities Act (2003) provides a comprehensive legal framework which outlaws all forms of discriminative treatment of persons with disability. The Sessional Paper no. 1 of 2005 states in part the overall government policy direction on SNE learners. The government is aware that special education has not been mainstreamed in all education subsectors and programmes. The government signed Article 26 of the Universal Declaration of Human Rights (1948), consequently recognizing and committing itself to the right of every child to access education.

In our African communities disability is explained to be results from God's punishment for some person's problems. Such superstitions have led many parents who give birth to children who deviate from the 'normal' to hide them hence deny them access to education. Mental Retardation (MR) is one of the most distressing handicaps in any society. Thus investigation of factors that may facilitate or inhibit social development assumes particular importance.

A particular environmental setup in which a child grows up is likely to play an important part in improving or deteriorating the child's functioning in a social milieu. This study was concerned with the factors inhibiting the mentally challenged learners in the acquisition of learning skills like social and activities of daily living skills unlike the rest of the learners in regular classroom. The purpose of this study was therefore to explore the factors inhibiting the mentally challenged in the acquisition of skills in special schools and units. The objectives of the study were: -

a) To establish the challenges facing mentally handicapped learners in acquisition of learning skills in special schools and units.

b) To establish the effect of parents support and involvement on the acquisition of learning skills among mentally handicapped learners in special schools and units. 
c) To establish the effect of community support and involvement on the acquisition of learning skills among mentally handicapped learners in special schools and units.

d) To determine the effect of the role of teachers and teaching methods used on the acquisition of learning skills among mentally handicapped learners in special schools

e) To find out the effect of learners characteristics on the acquisition of learning skills among mentally handicapped learners in special schools and units.

\section{METHODOLOGY}

Descriptive survey design was used for the study. The purpose of surveys is diverse and may not have only descriptive aspect but also seek to understand phenomena by identifying influencing factors (Bill, 2003). The descriptive design was considered relevant due to its ability to identify the factors inhibiting the acquisition of learning skills by the mentally challenged learners in special schools and their general performance. It also involved acquiring information about the mentally challenged learners, getting parents and teachers' opinions and attitudes or previous experiences by asking those questions. The study focused on the factors inhibiting the mentally challenged in the acquisition of learning skills in Ugenya district in Siaya county Nyanza province. The Study was guided by Social Justice theory proposed by Rawls (1971) and Theory of Opportunity by Montessori (1974). The theory of social Justice explains that justice is considering the welfare of the worst-off or the disadvantaged members as an obligation. According to Montessori (1974) in the theory of Opportunity, everyone should be educated regardless of age, gender, race or class. She believed that education is simply a result of an individual's experiences. In the conceptual framework below, the independent variables are: parents and community support and participation in learning of the handicapped, teacher characteristics and teaching methods for the mentally challenged learners and learner characteristics while the dependent variable is the acquisition of learning skills among the mentally handicapped learners. The intervening variable for the study is the school environment which includes the availability of teaching and learning resources. 


\section{Intervening Variables}

The school environment

- Availability of teaching and learning resources

Parents and community support and participation in learning of the handicapped

\section{Teacher characteristics and teaching methods for the mentally challenged learners}

Learner Characteristics

- Commitment to learning

- Age

- Gender
Acquisition of learning skills among the Mentallv Handicapped

Dependent Variable

\section{Independent Variables}

Fig.1: Factors inhibiting the Mentally Challenged in the acquisition of Skills.

\section{RESEARCH RESULTS}

\section{Distribution of Teachers by Highest professional Qualifications}

The study found that 20\% had Diploma, 67\% had Bachelors Degree and that 13\% of the respondents had Masters Degree in special education respectively. From the findings of the study, it can be said that most of the teachers interviewed were qualified and therefore were expected to have an idea about different factors affect the acquisition of learning skills among the mentally challenged students. The findings of the study were as presented in Figure 2.

Fig2: Distribution of Teachers by Highest professional Qualifications

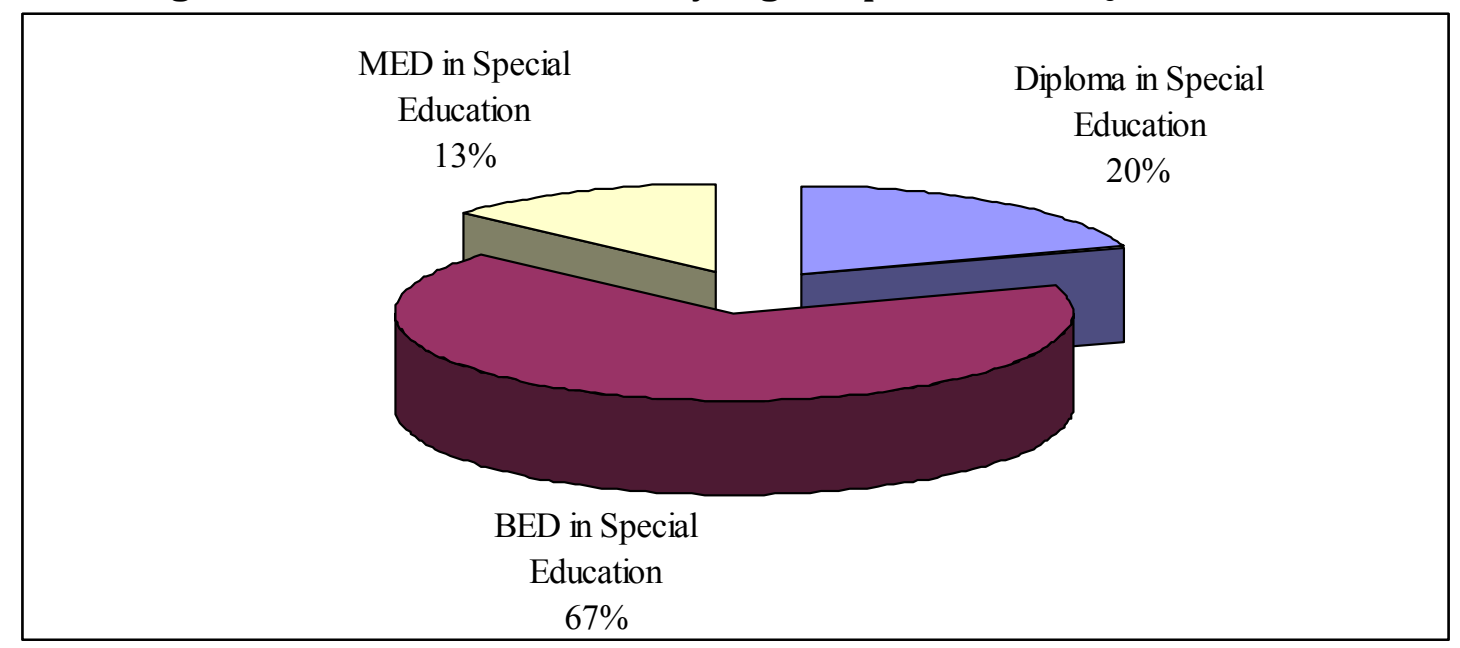




\section{Distribution of Teachers by Teaching Experience}

The study found that $33 \%$ of the teachers had taught for a period between 16-20 years. The study also found that $27 \%$ of teachers had taught for a period between $11-15$ years, $20 \%$ had taught for a period between 6-10 years and that 13\% had taught for a period of 5 years. Only $7 \%$ of the teachers had taught for a period above 50 years. From the findings of the study, it can be said that most of the teacher have a lot of information on the factors influencing acquisition of learning skills among mentally challenged students (Fig 3).

Figure 3: Distribution of Teachers by Teaching Experience

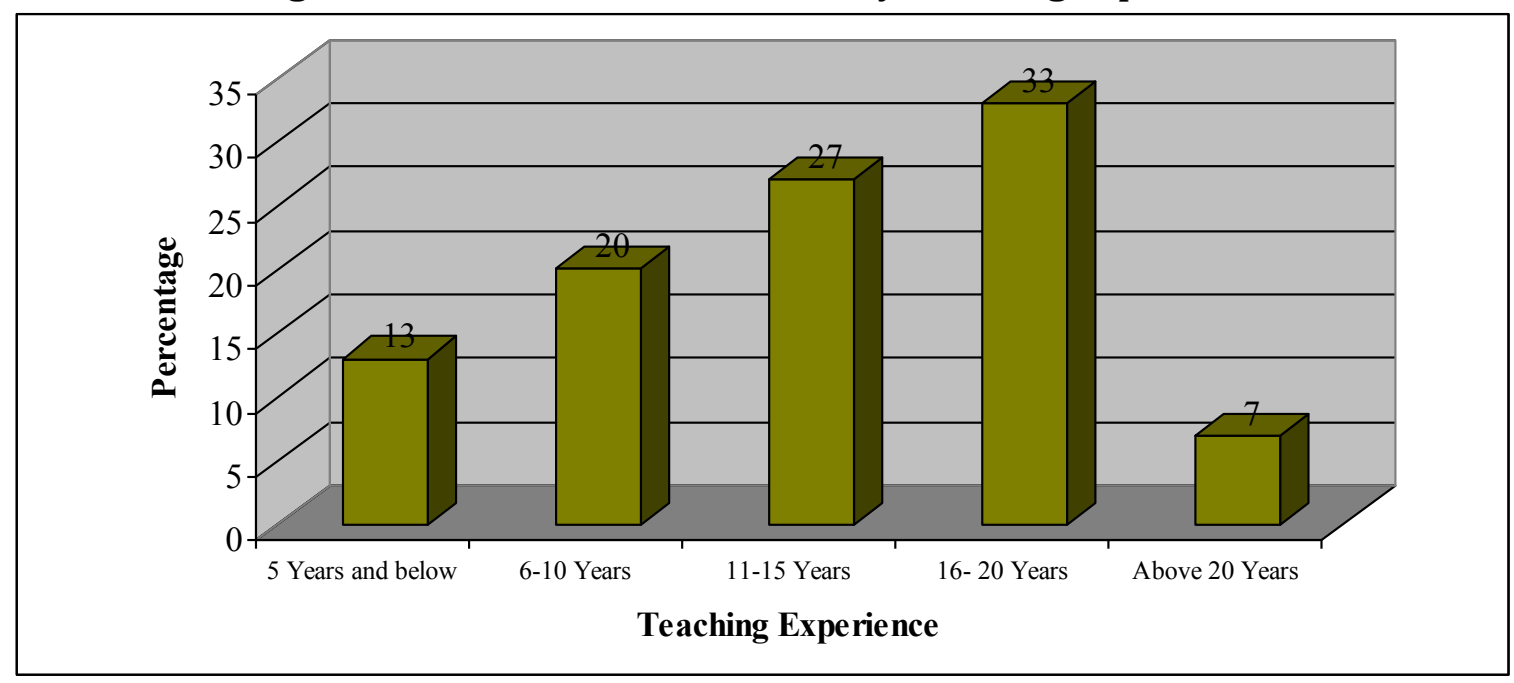

\section{Distribution of Parents/Guardians by Parenting Experience}

The study found in table 1 , that $40 \%$ of the respondent had been parents for a period above 20 years also $30 \%$ of the respondents had been parents for a period between 16-20 years, $17 \%$ for a period of 11-15 years, 9\% for a period of 6-10 years and 4\% for a period of 5 years.

Table 1: Distribution of Parents/Guardians by Parenting Experience

\begin{tabular}{|l|c|c|}
\hline Parenting/guarding Experience & Frequency & Percentage \\
\hline 5 Years and below & 2 & 4 \\
\hline 6-10 Years & 5 & 9 \\
\hline 11-15 Years & 9 & 17 \\
\hline 16-20 Years & 16 & 30 \\
\hline Above 20 Years & 22 & 40 \\
\hline Total & $\mathbf{5 4}$ & $\mathbf{1 0 0}$ \\
\hline
\end{tabular}

\section{Challenges facing Mentally Handicapped Learners in Acquisition of Learning Skills}

In establishing the challenges facing the mentally retarded children in the acquisition of learning skills, the respondents were asked to indicate the extent to which some of the perceived challenges affected the mentally challenged. This was tested on a four point Likert Scale of 1-4; where 1 represented 'Very challenging', 2 represented 'Challenging', 3 represented 'Less challenging' and 4 represented 'Not challenging at all'. The scores 'Very challenging" was taken to be equivalent to mean score ranging from 0.0 to 1.0, "Challenging" with mean score ranging from 1.1 to 2.0. 'Less challenging' with a mean score ranging from 2.1 to 3.0, and "Not challenging at all" with a mean score ranging from 3.1 to 4.0. A standard deviation of $>1$ represents a significant difference in the responses given. Table 2 presents the findings. 
Opondo, D. A., Kimengi, I. N., \& Sika, J. (2015). Factors Inhibiting the Mentally Challenged in the Acquistion of Skills in Ugenya District, Siaya county, Kenya. Advances in Social Sciences Research Journal, 2(4) 149-160.

Table2: Challenges of acquisition of Learning Skills among the Mentally Challenged

\begin{tabular}{|l|l|l|l|}
\hline & \multicolumn{1}{|c|}{ Number } & \multicolumn{1}{c|}{ Mean } & Standard Deviation \\
\hline Involvement in interruptive behaviours & 15 & 1.53 & .915 \\
\hline Reduced cognitive functioning & 15 & 1.27 & .594 \\
\hline Inability to cope with frustrations & 15 & 1.67 & .617 \\
\hline Less social interaction among learners & 15 & 2.33 & .900 \\
\hline
\end{tabular}

The findings on Table 2 shows that students' involvement in interruptive behaviours which interferes with learning, reduced cognitive functioning and inability to cope with frustrations were challenging in the acquisition of learning skills among children who were mentally challenged (mean score between 1.1 to 2.0). Baker et al. (2002) reported corroborating evidence that parents of children with developmental delays were more stressed than parents of children without delays. But Baker et al. also reported that in predicting parent stress in parents of children with developmental delays, child behavior problems accounted for significantly more of the variance than the children's level of cognitive functioning. Further, cognitive functioning contributed non-meaningfully when behavior problems were entered first in regression analyses, implying that behavior problems rather than cognitive level per se play the key role in parents' stress levels. The study also found that less social interaction among students was less challenging in the acquisition of learning skills among the mentally challenged students (mean score of 2.33).

The respondents were further asked to give other challenges facing the acquisition of learning skills among mentally challenged students. The following challenges were mentioned: lack teaching/learning resources by the teachers, lack of cooperation between the parents and guardians and the teachers; inadequate funds to support the children, none continuity in learning during school holidays and serious epileptic attacks that details the learners' acquisition of the learned skills and other health problems and lack of motivation among teachers.

\section{Parents and the Community Support and Involvement}

The study found that $53 \%$ of parents and the community were involved in the acquisition of learning skills among the mentally challenged while $47 \%$ were not involved. From the findings of the study, it can be said that parents and the community were not fully involved in the acquisition of learning skills among the mentally challenged students. The findings of the study were as presented in Figure 4.

Figure 4: Parents and the Community Support and Involvement

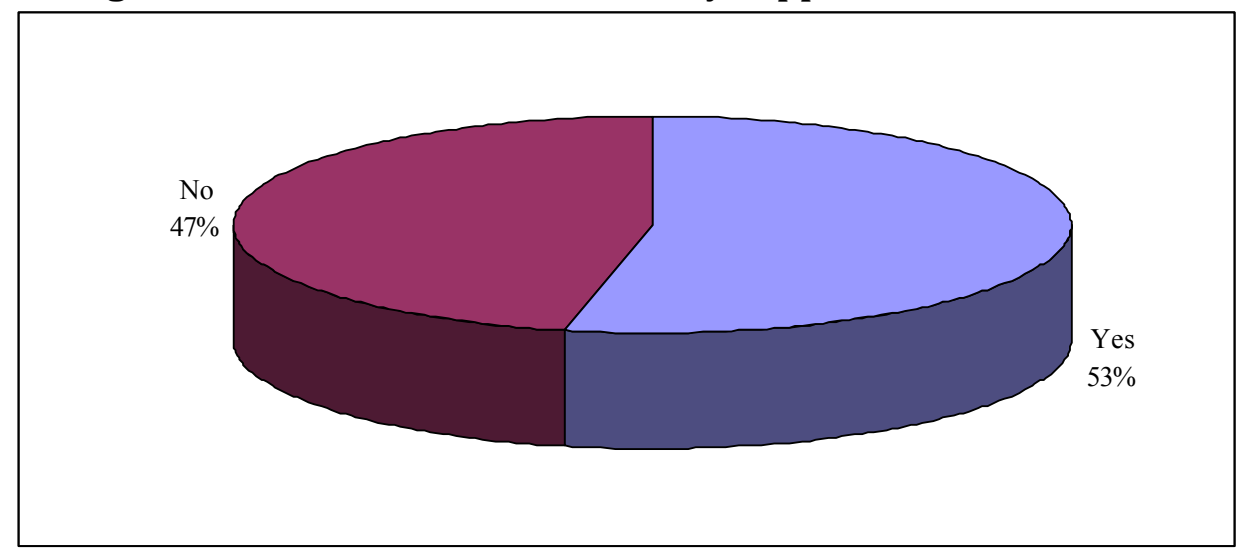




\section{Effect of None Participation Parents on the learning of the Mentally Retarded}

The study found that all the respondents (100\%) indicated that their participation affected the learning of the mentally retarded. According to Sen (2000), the interactions of parents with their children with disabilities can have a profound impact on the development and progress of the child. Thus none involvement of the parents and the community is perceived to impact on their children's developmental abilities and acquisition of learning skills. From the findings of the study, it can be said that the participation of parents and community affects learning among the mentally retarded students. The findings of the study were as presented in Table 3

Table 3: Effect of None Participation Parents on the learning of the Mentally Retarded

\begin{tabular}{|l|c|c|}
\hline Response & Frequency & Percentage \\
\hline Yes & 15 & 100 \\
\hline No & 0 & 100 \\
\hline Total & $\mathbf{1 5}$ & $\mathbf{1 0 0}$ \\
\hline
\end{tabular}

\section{Factors Influencing Parent's involvement in Learning of the Mentally Handicapped}

The findings on Table 4 shows that age of the child, the level of the disability, and socioeconomic status of the family influenced parents' involvement to a large extent (mean score between 1.1 to 2.0). The study also found that education level of the parent influenced their involvement to a small extent (mean score 2.11). The study finally found that the gender of the parents and the student does not affect their involvement at all. There was a significant difference in the responses given on the factors influencing parents' involvement in the learning of the mentally handicapped students except on the level of disability. From the findings of the study, it can be said that the major factors influencing parents' involvement in the learning of the mentally handicapped students are: age of the child, the level of the disability and socio-economic status of the family. Parents were further asked to mention other factors influencing their involvement in the learning of the mentally handicapped children, the following factors were mentioned:- lack of knowledge on type of disability, stigmatization and changes in child rearing practices; denial by majority of parents; lack of awareness among parents and community; the environment they live in either rural or urban; family size and beliefs and religious concerns. Table 4 presents the findings.

Table 4: Factors Influencing Parent's involvement in Learning of the Mentally Handicapped

\begin{tabular}{|l|c|c|c|}
\hline & Number & Mean & $\begin{array}{c}\text { Standard } \\
\text { Deviation }\end{array}$ \\
\hline $\begin{array}{l}\text { Age of the child (i.e. they participate more } \\
\text { on the early age) }\end{array}$ & 54 & 1.74 & 1.067 \\
\hline The gender of the child & 54 & 3.65 & 1.246 \\
\hline The level of the disability & 54 & 1.33 & .644 \\
\hline Gender of the parents & 54 & 3.70 & 1.110 \\
\hline Education level of the parents & 54 & 2.11 & 1.040 \\
\hline Socio-economic status of the family & 54 & 1.57 & 1.039 \\
\hline
\end{tabular}

\section{Ways in which Parents Participate in the learning among students with Learning Disability}

The study found that $80 \%$ of the respondents indicated that parents enquire on the performance of their children and keeps in touch with teachers to know of the progress. The study also found that $53 \%$ of the respondents indicated that parents often attend academic visiting days. The study further found that $46 \%$ of the respondents indicated that parents 
rarely provide children with adequate diet, shelter, clothing, medical care, education and guidance. This is an indication that despite the fact that parents provide their children with basic needs it is normally not sustainable especially for the mentally retarded. It was finally found that $40 \%$ of the respondents indicated that parents often protect their child from neglect, discrimination and abuse. The findings were as presented in Table 5.

Table 5: Ways in which Parents Participate among students with Learning Disability

\begin{tabular}{|l|c|c|c|c|c|}
\hline Participation and support & $\begin{array}{c}\text { Very } \\
\text { often }\end{array}$ & Often & Rarely & $\begin{array}{c}\text { Not at } \\
\text { all }\end{array}$ & $\begin{array}{c}\text { Total } \\
\text { (\%) }\end{array}$ \\
\hline $\begin{array}{l}\text { Providing children with adequate diet, } \\
\text { shelter, clothing, medical care, education } \\
\text { and guidance }\end{array}$ & 20 & 27 & 46 & 7 & $\mathbf{1 0 0}$ \\
\hline $\begin{array}{l}\text { Protecting the child from neglect, } \\
\text { discrimination and abuse }\end{array}$ & 20 & 40 & 33 & 7 & $\mathbf{1 0 0}$ \\
\hline Attending academic/visiting days & 27 & 53 & 13 & 7 & $\mathbf{1 0 0}$ \\
\hline $\begin{array}{l}\text { Enquiring on the performance of their } \\
\text { children and keeps in touch with teachers } \\
\text { to know of the progress }\end{array}$ & 80 & 13 & 7 & 0 & $\mathbf{1 0 0}$ \\
\hline
\end{tabular}

Teacher respondents were asked to mention other ways by which parents and the community participate in the learning of the mentally retarded children. The following ways were mentioned: paying for whatever is required in school inclusive of school fees, giving correct general information about the learner, inquiring more about the learner, guiding the learner and attending workshops organized in school.

\section{Continuity of Children's Learning at Home}

The study found that $67 \%$ of the respondents indicated that there was continuity of children learning. The findings are in line with the findings by Deslandes et al. (1999) who reported that parents of special education students were less involved in supervision of the adolescents' in learning activities at home, in participating at school as audience than parents of general education. The study also found that $6 \%$ indicated that there was no continuity of children's learning at home. The study finally found that $27 \%$ of the respondents indicated that they were not sure on whether there was continuity in children's learning at home. The findings of the study were as presented in Figure 5.

Figure 5: Continuity of Children's learning at Home

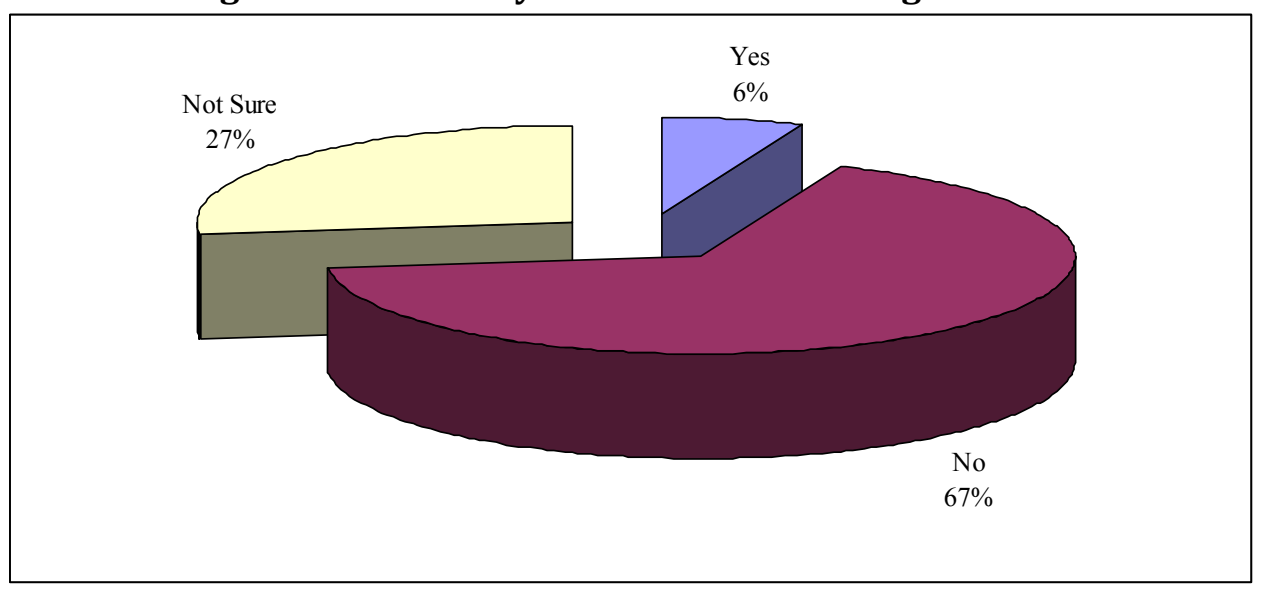


The respondents were further asked to explain their answers. Those who indicated that there was no continuous learning at home explained that parents never take their time to ensure that their children study while at home because learning is left for school only and duty of teachers.

\section{Community Support on Learning among the Mentally Retarded Children}

Teacher respondents were asked to indicate whether the community is supporting in the learning of the mentally retarded children in their schools. The study found that $67 \%$ of the respondents indicated that the community supported learning among children who are mentally retarded while $33 \%$ indicated that the community is not supportive in their learning. The findings of the study were as presented in Figure 6.

Figure 6: Community Support on Learning among the Mentally Retarded Children

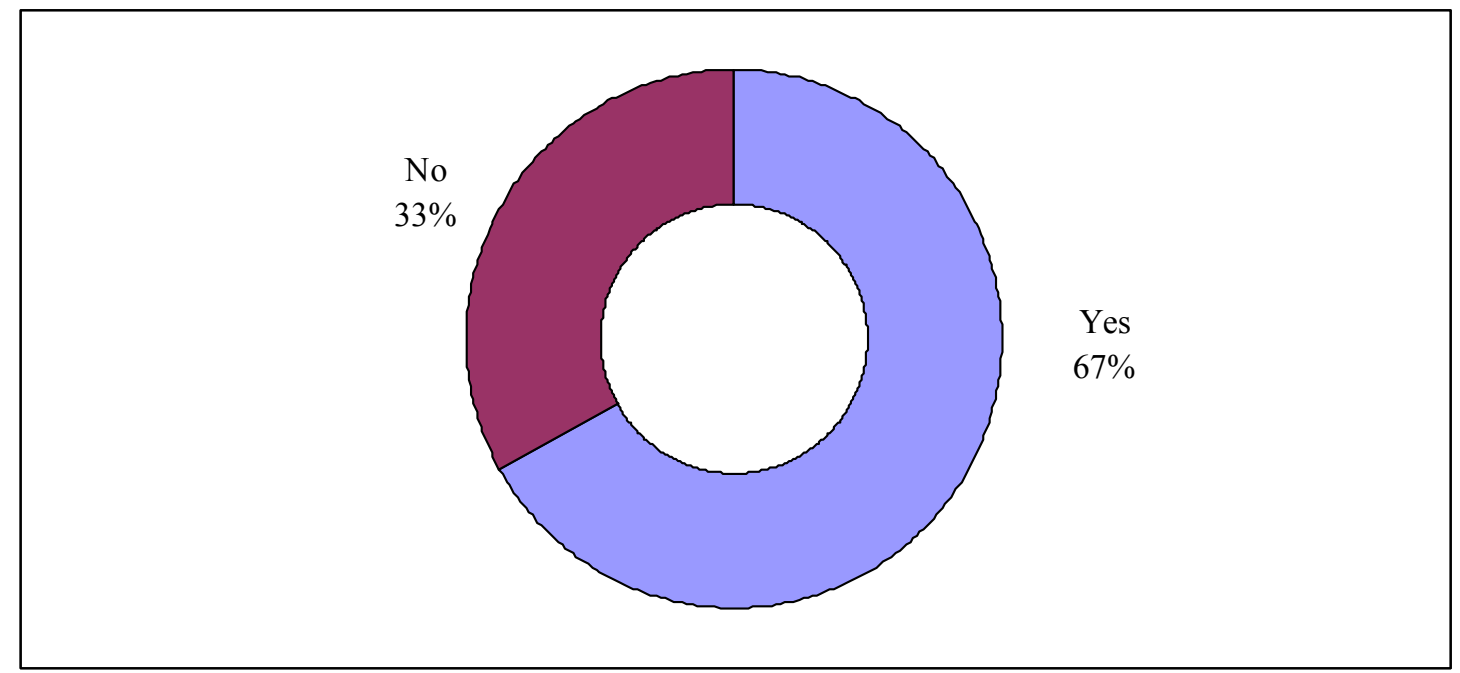

The respondents were further asked to explain their responses. The following explanations were given: through allocation of CDF funds as fees to support the poor learners in boarding schools, encouraging the establishment and development of special units in regular schools, provision of earning materials and building of classrooms.

\section{Categories of the Mentally Challenged Students}

The teacher respondents were asked to indicate the number of students they handled who had different kinds of mental illnesses. The findings were as presented in Table 6 . The findings show that most of the students $48 \%$ suffered from mild mental retardation. This is an indication that many have the chance to learn and still be competent members of the society. The study also found that $30 \%$ of the students suffered from moderate mental illness, $7 \%$ suffered from learning disability, $6 \%$ suffered from severe mental illness, 5\% were epileptic and $5 \%$ were autistic.

Table 6: Categories of the Mentally Challenged Students

\begin{tabular}{|l|c|c|}
\hline Mental illness & Number & $\begin{array}{c}\text { Percentage } \\
(\mathbf{\%})\end{array}$ \\
\hline Mild & 39 & 48 \\
\hline Moderate & 25 & 30 \\
\hline Severe & 5 & 6 \\
\hline Autistic & 3 & 4 \\
\hline LD & 6 & 7 \\
\hline Epileptic & 4 & 5 \\
\hline Total & $\mathbf{8 2}$ & $\mathbf{1 0 0 \%}$ \\
\hline
\end{tabular}


Opondo, D. A., Kimengi, I. N., \& Sika, J. (2015). Factors Inhibiting the Mentally Challenged in the Acquistion of Skills in Ugenya District, Siaya county, Kenya. Advances in Social Sciences Research Journal, 2(4) 149-160.

\section{Skills being taught and the Teaching Methods used for Mentally Retarded Children}

The following skills are being taught: Communication Skills, Self Help Skills, Social Skills, ADL Skills, Perceptual Training Skills, Tailoring, Agriculture, Carpentry. Teacher respondents were asked to indicate the teaching methods they use for the mentally retarded children. The following methods were mentioned: Task analysis, peer tutoring, Role play, Demonstration, Question and Answer, Discussion.

\section{Attitude of the Mentally Retarded Children towards Learning}

Teacher respondents were asked to indicate the attitudes of the mentally challenged children's towards learning. The study found that $60 \%$ of the teachers indicated that the children had a positive attitude towards learning while $40 \%$ had a negative attitude towards learning. From the findings of the study, it can be said that most of the children were still willing to learn besides their condition of mental retardation. The findings of the study were as presented in Table 7.

Table 7: Attitude of the Mentally Retarded Children towards Learning

\begin{tabular}{|c|c|c|}
\hline Attitude towards learning & Frequency & Percentage \\
\hline Negative attitude & 6 & 40 \\
\hline Positive attitude & 9 & 60 \\
\hline Total & $\mathbf{1 5}$ & $\mathbf{1 0 0 \%}$ \\
\hline
\end{tabular}

\section{Learners Characteristics which interferes with their Acquisition of Learning Skills}

The study found that $73 \%$ indicated that the acquisition of learning skills among mentally retarded learners is determined by their determination to acquire knowledge to a very large extent. Thus learners who are not determined find it difficult to acquire learning skills. The study also found that $53 \%$ of the respondents indicated that indicated that the children's gender interfered with their knowledge acquisition to a small extent. Frey et al. (1989) in his study, examined that father adaptation to girls (as opposed to boys) with disabilities seems better. Whereas Bailey et al. (1999) reported that gender of mental retarded children have no influence on the awareness, use of services and satisfaction of services reported by both mother and father of the children. The study finally found that the age of the learner interfered with their acquisition of knowledge to a large extent as indicated by $60 \%$ of the respondents. The findings are supported by the findings of Neeley-Barnes et al. (2008) who found that family receives more services and highly involved in decision making when persons with developmental disabilities were younger. Similarly, Ly (2008) explained that child's age influenced parent's behavior ratings of encouragement and less help because they perceived older children to have higher ability and effort. The findings of the study were as presented in Table 8.

Table 8:Learners Characteristics which interferes with their Acquisition of Learning Skills

\begin{tabular}{|l|l|l|l|l|l|l|}
\hline $\begin{array}{c}\text { Learner } \\
\text { Characteristic }\end{array}$ & $\begin{array}{l}\text { Very large } \\
\text { extent }\end{array}$ & $\begin{array}{l}\text { Large } \\
\text { extent }\end{array}$ & $\begin{array}{l}\text { Moderate } \\
\text { extent }\end{array}$ & $\begin{array}{l}\text { Small } \\
\text { extent }\end{array}$ & $\begin{array}{l}\text { No extent } \\
\text { at all }\end{array}$ & $\begin{array}{l}\text { Total } \\
(\mathbf{\%})\end{array}$ \\
\hline age of the learner & 20 & 60 & 13 & 7 & 0 & $\mathbf{1 0 0}$ \\
\hline gender of the learner & 7 & 13 & 27 & 53 & 0 & $\mathbf{1 0 0}$ \\
\hline $\begin{array}{l}\text { Learners determination } \\
\text { To acquire } \\
\text { knowledge }\end{array}$ & 73 & 27 & 0 & 0 & 0 & $\mathbf{1 0 0}$ \\
\hline
\end{tabular}


The respondents were further asked to mention some of the learners' characteristics which interfere with their acquisition of learning skills. The following characteristics were mentioned: low attention span, lack of eye-hand coordination, the severity of the disability, the epileptic attacks and other health problems that makes the condition progressive to the negative.

\section{CONCLUSIONS}

From the findings of the study, it can be concluded that the major challenges facing the acquisition of learning among the mentally handicapped included: students' involvement in interruptive behaviours which interferes with learning, reduced cognitive functioning and inability to cope with frustrations were challenging in the acquisition of learning skills among children who were mentally challenged. In addition the study revealed that the parents and the community were involved in the learning of the mentally challenged student. It further found that the role of teachers and teaching methods was not a hindrance to the acquisition of learning skills among the mentally challenged students. The study finally concluded that learners characteristics such as: low attention span, lack of eye-hand coordination, the severity of the disability, the epileptic attacks and other health problems that makes the condition progressive to the negative affected their acquisition of learning skills.

\section{RECOMMENDATIONS}

The study recommended that parents should provide the basic needs to allow continuity of skills at home and that learning materials and environment should be adapted in order to suit the needs of learners with mental handicap. It was recommended that awareness should be created through dissemination of information on mental handicap learners. This will help parents and society to take the learning of the mentally challenged easily thus promoting acquisition of learning skills among them. It was also recommended that the community should develop positive attitude towards the mentally challenged learners. Regarding the role of teachers and teaching methods, the study recommended that the mentally challenged learners should be handled by SNE teachers only and so more teachers should be trained to cub up the number as the ration is $1: 10$. it was also recommended that different varieties of learning and teaching materials should be provided.

It was recommended that learners should be encouraged to know that they can also learn just like others and that conducive environment suiting the level of their disability should be created for their learning.

\section{References}

Anderson, V. H., Schlottman, R. S. and Weiner, B. J., (1975). Predictors of parents' involvement with institutionalized retarded children. Am. J. Ment Defic, 79: 705- 710.

Bailey, D. B., Skinner, D., Rodriguez, P., Gut, D. and Correa, V., (1999), Awareness, use, and satisfaction with services for latino parents of young children with disabilities. Except Child. 65 (3): 367-381.

Baker, B. L., Blacher, J. and Pfieffer, S. I., (1996). Family involvement in residential treatment. A m. J. Ment Retard. 101 (1): 1-14.

Deslandes, R., Royer, E., Potvin, P. and Leclerc, D., (1999). Patterns of home and school partnership for general and special education students at the secondary level. Except. Child. 65 (4): 496-506.

Epstein J.L (2001). School, family and community partnerships: - Preparing education and improving schools. Boulder, co: - West views press.

Frey, K. S., Greenberg, M. T and Fewell, R. R., (1989), Stress and coping among parents of handicapped children: A multidimensional approach. Am. J. Ment. Retard. 94: 240-249.

KIE (2001). (mathematics skills syllabus 4th draft. Nairobi, Kenya). 
Opondo, D. A., Kimengi, I. N., \& Sika, J. (2015). Factors Inhibiting the Mentally Challenged in the Acquistion of Skills in Ugenya District, Siaya county, Kenya. Advances in Social Sciences Research Journal, 2(4) 149-160.

Ly, T. M., 2008, Asian American parents' attributions of children with Down syndrome: Connections with child characteristics and culture. Intellect. Dev. Disabil. 46 (2): 269

Montessori, M. (1974). Childhood education. Raleigh, NC: Contemporary Books, Inc. (CE)Montessori, M. (1967). The discovery of the child. New York: NY: Fides Publisher.

Neely-Barnes, S., Graff, J. C., Marcenko, M. and Weber, L., (2008). Family decision making: Benefits to persons with developmental disabilities and their family members. Intellect. Dev. Disabil. 40 (2): 93-105.

Ngugi M.W (2002). Introduction to Inclusive Education KISE Nairobi Kenya.

Rawls J (1971). A Theory of justice Cambridge Massachusetts: - The Belknap of Harvard University Press.

Sen. A. K., (2000). Research in mental retardation in India: Challenges and opportunities. Psychological Studies. 45 (3): $139-144$.

Zedin, A. G. and Turner, J. L., (1984). Self-perspectives on being handicapped: Stigma and adjustment. Washington, DC: American Association on Mental Deficiency. (Cited in: Clare et al., 1998). 